\title{
UPAYA PELESTARIAN KESENIAN DAN BUDAYA LOKAL DI KABUPATEN LAMPUNG BARAT
}

\section{EFFERTS TO PRESERVE LOCAL ARTS AND CULTORE IN WEST LAMPUNG DISTRICT}

\begin{tabular}{|c|c|}
\hline $\begin{array}{l}\text { Meriwijaya }^{1} \\
\text { Universitas Selamat } \\
\text { Sri, Indonesia } \\
\text { email: } \\
\text { meriwijaya@ymail.co } \\
\text { m } \\
\text { Luth }^{2} \\
\text { Universitas Selamat } \\
\text { Sri, Indonesia }{ }^{2} \\
\text { email: } \\
\text { lutfiaswar@gmail.com }\end{array}$ & 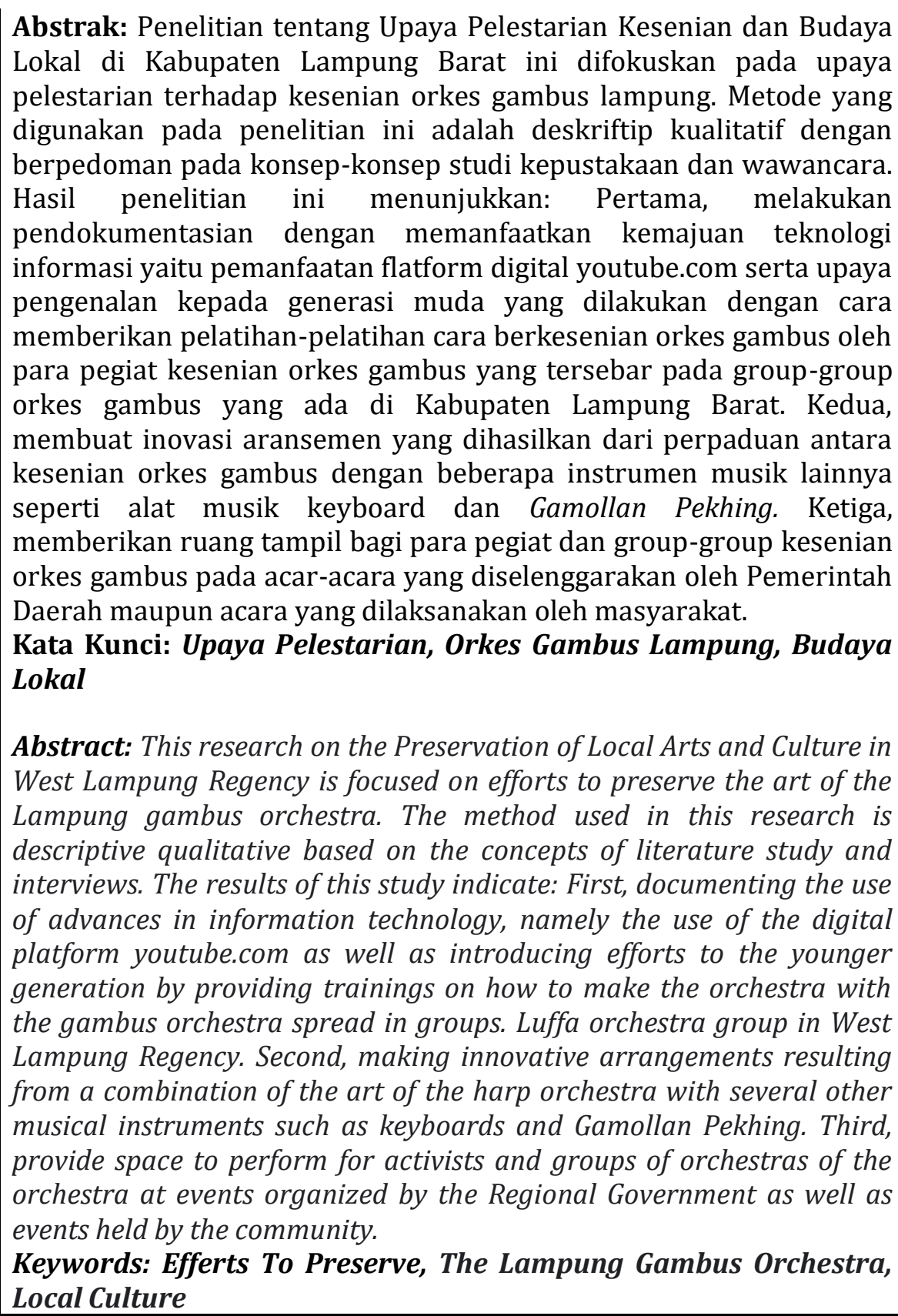 \\
\hline
\end{tabular}

\section{PENDAHULUAN}

Kabupaten Lampung Barat dalam sejarah asal-usul bangsa Lampung merupakan daerah asal masyarakat Lampung yaitu berasal dari kerajaan Sekala Brak yang merupakan sebuah kerajaan yang terletak di dataran Belalau, sebelah selatan danau ranau yang saat ini secara admnistratif berada di Kabupaten Lampung Barat 
(lampungbaratkab.go.id/detailpost/budaya: akses 10 April 2021). Dengan fakta tersebut tidak dimungkiri bahwa adanya kerajaan Sekala Brak sangat berpengaruh terhadap keberagaman kesenian dan kebudayaan lokal (Tradisional) yang ada di Kabupaten Lampung Barat. Dari berbagai kesenian dan kebudayaan lokal di Kabupaten Lampung Barat yang tetap eksis dan dilestarikan sampai saat ini antara lain: Orkes Gambus Lampung, Nyambai, Hadra, Betattah, Muayak dan pesta budaya yaitu Budaya Sekura.

Dari berbagai kesenian dan budaya lokal tersebut, Orkes Gambus Lampung merupakan salah satu kesenian lokal yang terpopuler di era tahun 1970 hingga tahun 2000. Kesenian Orkes Gambus Lampung (dalam Fathan Maheswara, 2020) adalah sebuah ansambel musik tradisional yang berkembang di seluruh wilayah pesisir yang ada di Lampung, termasuk Lampung Barat. Kesenian ini pertama kali hadir ke wilayah Lampung Barat pada tahun 1972. Pada awalnya instrumen yang dipakai Orkes Gambus Lampung adalah Gambus, Ketipung (Gendang), Piyul (Biola), Meruas (Tamborine) dan Bas, namun seiring dengan berkembangnya zaman Orkes Gambus Lampung juga mulai menggunakan instrumen musik modern seperti Piano, Keyboard dan Gitar.

Kesenian Orkes Gambus Lampung selain sebagai sarana hiburan, dikalangan masyarakat Lampung khususnya di Kabupaten Lampung Barat kesenian ini justru sering kali digunakan sebagai media pemersatu dan ajang silaturahmi antar sesama masyarakat khususnya kaum muda-mudi serta kelompok-kelompok pegiat kesenian orkes gambus yang tersebar di sebagian besar wilayah yang ada di Kabupaten Lampung Barat. Berbagai kegiatan yang bertajuk pertival, pesta budaya serta acara-acara hajatan di Lampung Barat banyak menghadirkan Kesenian Orkes Gambus Lampung sebagai sarana hiburan.

Permasalahan yang muncul kemudian setelah tahun 2000 kesenian orkes gambus lampung khususnya di Kabupaten Lampung Barat sudah mulai ditingalkan. Perkembangan zaman serta adanya arus globalisasi mengakibatkan banyak perubahanperubahan yang terjadi di dalam pola kehidupan masyarakat, yang juga berpengaruh pada kebudayaan masyarakat itu sendiri. Era globalisasi dapat menimbulkan perubahan pola hidup masyarakat yang lebih modern, akibatnya masyarakat cenderung untuk memilih kebudayaan baru yang dinilai lebih praktis dibandingkan dengan budaya lokal. Salah satu perubahan yang paling nyata dapat dilihat dari berkurangnya perhatian, kesadaran, minat, serta ketertarikan generasi muda ataupun masyarakat pada umumnya terhadap kesenian dan kebudayaan tradisional, jika ditinjau dan dibandingkan dengan 
kesenian dan kebudayaan yang sifatnya modern, maka generasi muda lebih tertarik terhadap kesenian dan kebudayaan modern tersebut, karena kesenian dan kebudayaan modern dianggap bersifat lebih bebas, lebih segar, dan lebih baru. Tidak bisa ditampik bahwa kesenian tradisional orkes gambus lampung di Kabupaten Lampung Barat baru kembali muncul sejak era kepemimpinan Bupati Hi. Parosil Mabsus, S.Pd. dan Wakil Bupati Drs. H. Mad Hasnurin dalam beberapa tahun terakhir.

Untuk mengatasi hal tersebut perlu kesadaran akan pentingnya kesenian dan budaya lokal sebagai jati diri bangsa. Kewajiban bagi setiap lapisan masyarakat untuk mempertahankannya, di mana peran generasi muda sangat diharapkan untuk terus berusaha mewarisi kesenian dan budaya lokal yang akan menjadi kekuatan bagi eksistensi kesenian dan budaya lokal itu sendiri walaupun diterpa arus globalisasi. Faktor lain yang menyebabkan kesenian dan budaya lokal dilupakan dimasa sekarang adalah kurangnya generasi penerus yang memiliki minat untuk belajar dan mewarisi kesenian dan kebudayaannya sendiri. Oleh karena itu, perlu adanya upaya yang dilakukan untuk melestarikan kesenian dan kebudayaan lokal di era globalisasi ini. A.W. Widjaja (1986) mengartikan pelestarian sebagai kegiatan atau yang dilakukan secara terus menerus, terarah dan terpadu guna mewujudkan tujuan tertentu yang mencerminkan adanya sesuatu yang tetap dan abadi, bersifat dinamis, luwes, dan selektif (Jacobus, 2006:115). Sedangkan, pengertian pelestarian dalam Kamus Besar Bahasa Indonesia (2001:665) berasal dari kata Lestari yang memiliki arti tetap seperti keadaannya semula, tidak berubah, bertahan, kekal, maka pelestarian diartikan sebagai proses, cara, perbuatan melestarikan, perlindungan dari kemusnahan atau kerusakan, penggawetan, konservasi.

Menurut Edi, S (2006:21) agar suatu kebudayaan dapat lestari yaitu selalu ada eksistensinya, upaya-upaya yang perlu dijamin kelangsungannya meliputi: Pertama, Perlindungan yaitu meliputi upaya-upaya agar hasil-hasil budaya tidak hilang atau rusak. Kedua, Pengembangan yang meliputi pengolahan yang menghasilkan peningkatan mutu dan atau perluasan kawasan, dan Ketiga, Pemanfaatan meliputi upaya-upaya untuk menggunakan hasil-hasil budaya untuk berbagai keperluan seperti menekankan citra identitas suatu bangsa.

Berangkat dari fakta dan berbagai permasalahan yang telah diuraikan di atas, peneliti bermaksud untuk melakukan penelitian mengenai Upaya Pelestarian Kesenian Orkes Gambus di Kabupaten Lampung Barat, dengan tujuan penelitian untuk 
menggambarkan dan menganalisa tentang Upaya Pelestarian Kesenian Orkes Gambus di Kabupaten Lampung Barat, sehingga hasil penelitian ini diharapkan dapat bermanfaat dalam memberikan masukan untuk penambahan pengetahuan serta memperkaya khasanah kajian bidang kesenian dan kebudyaan lokal, menjadi bahan rujukan pengambilan keputusan serta memberi kontribusi informasi bagi semua pihak dalam melakukan pelestarian kesenian dan kebudayaan lokal, dan dapat dijadikan referensi atau pedoman bagi penelitian selanjutnya tentang pelestarian kesenian dan kebudayaan lokal, khususnya Kesenian Orkes Gambus Lampung.

\section{METODE}

Dalam penelitian ini penulis menggunakan metode deskriptif kualitatif yaitu membuat gambaran secara sistematis, faktual dan akurat mengenai fakta-fakta dan sifatsifat dari populasi atau daerah tertentu yang dijadikan objek atau subjek penelitian, sehingga dengan gambaran tersebut menghasilkan suatu pemikiran tentang Upaya Pelestarian Kesenian Orkes Gambus Lampung di Kabupaten Lampung Barat yang dapat diamati secara langsung pada saat penelitian dilakukan. Dalam metode ini analisis dilakukan pada identifikasi masalah dan penjabaran terhadap data yang dikumpulkan dengan berpedoman pada konsep-konsep studi kepustakaan yang relevan. Menurut M. Nazir dalam bukunya yang berjudul "Metode Penelitian" mengemukakan bahwa yang dimaksud dengan: Studi kepustakaan adalah teknik pengumpulan data dengan mengadakan studi penelaahan terhadap buku-buku, literatur-literatur, catatan-catatan, dan laporan-laporan yang ada hubungannya dengan masalah yang dipecahkan. Selanjutnya menurut Nazir (1998: 112) studi kepustakaan merupakan langkah yang penting dimana setelah seorang peneliti menetapkan topic penelitian, langkah selanjutnya adalah melakukan kajian yang berkaitan dengan teori yang berkaitan dengan topik penelitian. Dalam pencarian teori, peneliti akan mengumpulkan informasi sebanyak-banyaknya dari kepustakaan yang berhubungan. Sumber-sumber kepustakaan dapat diperoleh dari: buku, jurnal, majalah, hasil-hasil penelitian (tesis dan disertasi), dan sumber-sumber lainnya yang sesuai (internet, koran dll). Selain studi kepustakaan, peneliti juga melakukan wawancara terhadap beberapa pegiat kesenian orkes gambus sehingga dihasilkan deskripsi atau gambaran secara sistematis, faktual, dan akurat mengenai Upaya Pelestarian Kesenian Orkes Gambus di Kabupaten Lampung Barat. 


\section{HASIL DAN DISKUSI}

Berdasarkan hasil dan diskusi dalam penelitian tentang Upaya Pelestarian Kesenian dan Budaya Lokal di Kabupaten Lampung Barat dapat dijabarkan sebagai berikut:

\section{UPAYA PERLINDUNGAN ORKES GAMBUS LAMPUNG}

Upaya perlindungan terhadap kesenian tradisional merupakan upaya yang dilakukan agar kesenian tersebut tidak hilang atau rusak. Upaya perlindungan kesenian tradisional pada era globalisasi yang didukung dengan perkembangan teknologi informasi selain melalui sarana penguatan peraturan perundang-undangan dapat dilakukan melalui pendokumentasian yang merupakan upaya penting dalam melindungi kesenian tradiosional. Ada dua hal yang dapat dilakukan guna memberikan perlindungan atas kesenian tradisional:

\section{Jangka Pendek}

Untuk jangka pendek upaya perlindungan terhadap kesenian tradisional dapat dilakukan dengan sistem inventarisasi atau dokumentasi, hal ini tidak saja memberikan fungsi informatif tetapi juga dapat digunakan sebagai fungsi pembuktian hukum. Pendokumentasian dapat dilakukan dengan cara foto, vidio, tulisan atau catatan khusus yang dibuat oleh pemerintah. Berkaitan dengan hal tersebut upaya perlindungan jangka pendek terhadap kesenian orkes gambus di Kabupaten Lampung Barat sudah dilakukan oleh pemerintah Kabupaten Lampung Barat. Salah satu upaya tersebut dilakukan dengan pendokumentasian berupa vidio berbagai kegiatan yang berkaitan dengan kegiatan pertunjukan kesenian orkes gambus di Kabupaten Lampung Barat yang didokumentasikan melalui channel youtobe.com yang dikelola langsung oleh Dinas Kepemudaan Olahraga dan Pariwisata Kabupaten Lampung Barat dengan nama cahnnel Pariwisata Lampung Barat. Dengan demikian Pemeriantah Kabupaten Lampung Barat telah melakukan upaya perlindungan dengan pamanfaatan teknologi informasi untuk dapat melindungi kesenian orkes gambus.

\section{Jangka Menengah dan Jangka Panjang}

Perlindungan kesenian tradisional untuk jangka menengah dan jangka panjang dapat dilakukan dengan upaya memperkenalkan kesenian tradisional tersebut kepada generasi muda. Upaya pengenalan ini dimaksudkan agar kesenian tersebut tidak terjadi kepunahan dan terus dikembangan dan dinikmati oleh generasi-generasi yang akan datang. Selain itu, perlindungan jangka panjang terhadap kesenian tradisional juga dapat 
dilakukan dengan mengeluarkan peraturan yang secara khusus melindungi kesenian tradisional. Salah satu kelemahan kita dalam mengembangkan sistem perlindungan terhadap kesenian tradisional adalah sangat terbatasnya data, dokumentasi, dan informasi mengenai kesenian tradisional tersebut. Persoalan Hak Kekayaan Intelektual (HAKI) kerap menjadi isu panas khususnya dalam hal kesenian tradisional. Insiden diklaimnya kesenian Indonesia oleh negara tetangga menjadi bukti masih minimnya pemahaman dan kesadaran masyarakat serta kurangnya tingkat perlindungan hak kekayaanintelektual(https://nasional.kompas.com/read/2015/12/13/16520701/Penti ngnya.Hak.Cipta. untuk.Lindungi.Kesenian.Tradisional, (diakses pada 1 April 2021).

Berkaitan dengan hal tersebut, upaya memperkenalkan serta mempertahankan kesenian orkes gambus di Kabupaten Lampung Barat tidak hanya melalui upaya yang dilakukan pemerintah daerah akan tetapi upaya juga dilakukan oleh masyarakat khususnya kelompok-kelompok kesenian yang ada di Kabupaten Lampung Barat. Upaya pengenalan serta mempertahankan kesenian orkes gambus di Kabupaten Lampung Barat ini dibagi menjadi dua bagian yaitu upaya yang dilakukan oleh pemerintah daerah dan Upaya yang dilakukan oleh kelompok masyarakat.

\section{Upaya Pemerintah Daerah}

Dalam rangka memperkenalkan kesenian orkes gambus khususnya kepada generasi muda, pemerintah Kabupaten Lampung Barat tidak henti-hentinya melakukan berbagai upaya dengan tujuan agar kesenian orkes gambus ini terus dikenal dan tidak terjadi kepunahan. Salah satu upaya tersebut diujudkan dengan adanya pergelaran orkes gambus yang dilakukan oleh Pemerintah Kabupaten Lampung Barat yang bekerjasama dengan Karang Taruna Indonesia (KTI) Lampung Barat. Wujud pergelaran tersebut berupa pertival orkes gambus tingkat Kabupaten Lampung Barat dengan tujuan memberikan wadah kepada masyarakat khususnya pencinta dan pegiat kesenian orkes gambus serta generasi muda untuk mengasah kemampuan dan berinovasi sehingga kesenian orkes gambus di Kabupaten Lampung Barat tidak hanya sebagai warisan leluhur yang dicintai masyarakat setempat tetapi diharapkan terus dikembangkan dan diwariskan pada generasi-generasi muda mendatang (https://lampungbaratkab.go.id/detailpost/festival-orkes-gambus-akan-digelarnovember : Akses 10 Maret 2021).

Dalam gelaran yang dilaksanakan pada bulan november tahun 2019 di Pekon (Desa) Sukaraja, Kecamatan Batu Brak tersebut, terdapat 32 group orkes gambus yang 
turut berpartisipasi sebagai peserta yang berasal dari seluruh wilayah Kabupaten Lampung Barat. Sebagaimana informasi dikutip dari halaman website Media Lampung (medialampung.co.id) yang bertajuk "KTI Lambar Sukses Gelar Pertival Budaya Orkes Gambus" acara tersebut secara resmi ditutup oleh Staff Ahli Bidang Administrasi Umum Pemerintah Kabupaten Lampung Barat, Edi Yusuf, S.Sos., M.H dan dihadiri oleh Ketua KTI Lampung Barat Ahmad Ali Akbar, S.H yang merupakan anggota DPRD Kabupaten Lampung Barat. Dalam kegiatan tersebut, enam grup orkes gambus yang berhasil meraih gelar juara dalam beberapa kategori yaitu Grup Orkes Gambus Teba Pemata, Andan Mupakat, Ratai Grup, dan Silvana Way Mengaku yang berasal dari Kecamatan Balik Bukit, Grup Orkes Gambus Buay Benyata berasal dari Kecamatan Batu Ketulis dan Grup Orkes Gambus SBBW Kembahang yang berasal dari Kecamatan Batu Brak.

Selain pergelaran pestival diatas, dengan adanya perkembangan teknologi informasi diiringi oleh munculnya berbagai macam platform digital, Pemerintah Kabupaten Lampung Barat terus berinovasi dan melakukan penyesuaian terhadap kemajuan teknologi informasi dalam rangka ikut andil untuk melestarikan dan melakukan perlindungan terhadap kesenian orkes gambus ini. Hal tersebut dibuktikan dengan adanya pelaksanaan pergelaran orkes gambus secara virtual dengan tajuk “Pagelaran Virtual Orkes Gambus Tradisional Bumi Sekala Bekhak” yang menggunakan platform digital youtobe.com yang diselenggarakan oleh Dinas Kepemudaan Olahraga dan Pariwisata Kabupaten Lampung Barat melalui akun youtube.com "Pariwisata Lampung Barat" yang dikelola oleh Dinas Kepemudaan, Olahraga dan Pariwisata Kabupaten Lampung Barat. Dalam pergelaran tersebut, animo masyarakat untuk bisa ikut andil begitu besar, hal tersebut dibuktikan dengan jumlah peserta yang ambil bagian dalam pergelaran ini tersebar dari sebagian besar wilayah kecamatan yang ada di Kabupaten Lampung Barat. Dalam setiap Grup Orkes Gambus yang ikut berpartisipasi tersebut bahkan mengirim lebih dari satu kelompok musisinya sehingga peserta yang mengikuti pergelaran ini mencapai angka ratusan group orkes gambus. Adapun groupgroup orkes gambus yang mengirimkan perwakilannya kami rangkum sesui dengan tabel berikut: 
Tabel 1.

Daftar Peserta Pagearan Virtual Orkes Gambus Tradisional Bumi Sekala Bekhak

\begin{tabular}{|c|c|c|c|}
\hline No & Nama Group Orkes & Daerah Asal & Kecamatan \\
\hline 1 & Sanggar Banjarmasih & Padang Cahya & Balik Bukit \\
\hline 2 & Andan Mupakat & Gunung Sugih Liwa & Balik Bukit \\
\hline 3 & OG Diwangga & Way Mengaku & Balik Bukit \\
\hline 4 & Andan Muakhi Umbul Liyoh & Sebarus & Balik Bukit \\
\hline 5 & Angon Saka & Pekon Watas & Balik Bukit \\
\hline 6 & Ratai Grup & Sukarami & Balik Bukit \\
\hline 7 & OG Saliwa Group & Liwa & Balik Bukit \\
\hline 8 & OG Sang Muakhi Bahway & Bahway & Balik Bukit \\
\hline 9 & Andan Jejama & Kota Agung Liwa & Balik Bukit \\
\hline 10 & Sanggar Sebarus Sai & Sebarus & Balik Bukit \\
\hline 11 & OG Radeka & Kesugihan Baru & Balik Bukit \\
\hline 12 & Mutiara Group & Kurungan Aji & Balik Bukit \\
\hline 13 & OG Sinar Pesagi & Bah Way & Balik Bukit \\
\hline 14 & Rapi Lokal II & Lampung Barat & Balik Bukit \\
\hline 15 & Janji Muakhi & Pekon Bah Way & Balik Bukit \\
\hline 16 & Andan Jejama Titi Jelatong & Watas & Balik Bukit \\
\hline 17 & Gema Musik Tembelang & Banjar Negeri Suoh & Banjar Negeri Suoh \\
\hline 18 & Sumbay Sukajaya & Kerang & Batu Brak \\
\hline 19 & Andan Saka & Suka Raja & Batu Brak \\
\hline 20 & OG Semulli & Pekon Balak & Batu Brak \\
\hline 21 & Andan Jejama & Gunung Sugih & Batu Brak \\
\hline 22 & Salui Pitu & Pekon Balak & Batu Brak \\
\hline 23 & Sanggar Buay Bejalan Diway & Batu Brak & Batu Brak \\
\hline 24 & Teba Liokh & Teba Liokh & Batu Brak \\
\hline 25 & HRK Canggu & Canggu & Batu Brak \\
\hline 26 & Sanggar Jejama & Pekon Awi & Batu Brak \\
\hline 27 & OG Way Bapitu & Bakhu & Batu Ketulis \\
\hline 28 & Gemuttukh Agung & Bakhu & Batu Ketulis \\
\hline 29 & OG Seandanan & Way Ngison & Batu Ketulis \\
\hline 30 & Sanggar Way Ghemelai & Pekon Turgak & Belalau \\
\hline 31 & OG Bakhnasi Punyimbang Bawang & Pajar Agung & Belalau \\
\hline 32 & Limbang & Bedudu & Belalau \\
\hline 33 & Angkon Jejama & Turgak & Belalau \\
\hline 34 & Buay Benyata Group & Pekon Luas & Belalau \\
\hline 35 & Kilu Andan & Penengahan Turgak & Belalau \\
\hline 36 & Sanggar Luppak Way & Pekon Bumi Agung & Belalau \\
\hline 37 & Andan Muakhi Group & Kenali & Belalau \\
\hline 38 & OG Kilu Bimbing & Pekon Serungkuk & Belalau \\
\hline 39 & OG Pelimpuhan & Kebun Tebu & Kebun Tebu \\
\hline 40 & Himpun Muakhi & Pura Mekar & Kebun Tebu \\
\hline 41 & OG Seakkonan & Sekincau & Sekincau \\
\hline 42 & Bunguyan Bawang Ucung & 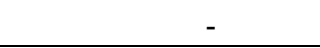 & - \\
\hline
\end{tabular}

Sumber: Olahan Data dari akun youtobe.com : Dinas Kepemudaan, Olahraga dan Pariwisata Kabupaten Lampung Barat

Berdasarkan tabel diatas, menggambarkan bahwa geliat pelestarian seni dan budaya di Kabupaten Lampung Barat mendapatkan dukungan dari masyarakat khususnya kelompok-kelompok pegiat kesenian orkes gambus. Hal tersebut sesuai dengan salah satu misi Bupati dan Wakil Bupati Lampung Barat yaitu "Mengembangkan Perikehidupan Masyarakat Yang Agamis, Berbudaya, Demokratis, Kesetaraan Gender dan Partisipatif". Adapun hasil dari Pagelaran Virtual Orkes Gambus Tradisional Bumi 
Sekala Bekhak yaitu Pertama, kategori like terbanyak yang dimenangkan oleh Orkes Gambus (OG) Andan Muakhi Kenali, OG Sumbai Sukajaya Kerang, dan OG Andan Jejama Gunung Sugih Batu Brak. Kedua, Kategori penampil terbaik yang dimenangkan oleh OG Ratai Grup, OG Diwangga, dan Andan Saka Sukaraja B, OG Kilu Andan Turgak, OG Pelimpuhan Kebun Tebu. Ketiga, Kategori Organisasi yang aktif dalam seni budaya daerah yang dimenangkan oleh OG Rapi Lokal II Wilayah VII. Keempat, Kategori penampil dengan busana terbaik dimenangkan oleh Sanggar Sebarus Sai. Kelima, Pemenang kategori penampil millenial yaitu OG Andan Muakhi Umbul Liyoh A, serta Kategori yang terakhir yaitu kategori group orkes legendaris (tertua dan eksis) dimenangkan oleh OG Punyimbang Bawang Limbang, OG HRK Canggu, OG Tunas Selalau dan OG Buway Bejalan Diway dengan masing-masing pemenang mendapatkan piagam pengargaan, trophy dan uang pembinaan (Sumber: Olahan data dari akun youtobe.com Dinas Kepemudaan, Olahraga dan Pariwisata Kabupaten Lampung Barat, diakses pada bulan Maret 2021, dari: https://www.youtube.com/watch?v=sW7n1JLjEDY\&t=409s).

Berdasarkan hasil pergelaran tersebut menunjukkan bahwa upaya pelestarian dan perlindungan terhadap kesenian tradisional yang dapat dilakukan dengan cara memperkenalkan kesenian dan kebudayaan terhadap generasi penerus yaitu generasi muda telah berhasil dilaksanakan oleh Pemerintah Kabupaten Lampung Barat yang dibuktikan dengan adanya pemenang pergelaran dengan kategori penampil millenial serta beberapa peserta lainnya yang diisi oleh generasi millenial bahkan masih anakanak. Selain itu, adanya kategori group orkes legendaris (tertua dan eksis) diharapkan dapat menjadi bahan acuan (Role model) bagi generasi muda dalam mempelajari cara berkesenian orkes gambus dan sebaliknya kehadiran grup-grup tersebut tentunya dapat memberikan bimbingan dan menjadi pelopor lahirnya grup-grup orkes gambus yang berisikan generasi-generasi muda sehingga tujuan pelestarian kesenian ini dapat terujud.

\section{Upaya Kelompok Masyarakat}

Upaya pelestarian dan perlindungan terhadap kesenian dan kebudayaan tradisional khususnya kesenian Orkes Gambus Lampung di Kabupaten Lampung Barat tidak hanya menjadi tanggung jawab pemerintah daerah, tetapi menjadi tanggung jawab semua elemen dalam masyarakat khususnya para pegiat kesenian orkes gambus Lampung dan masyarakat secara umumnya. Berkaitan dengan perihal tersebut berbagai upaya perlindungan dan pelestarian telah dilakukan oleh kelompok masyarakat dalam 
hal ini kelompok-kelompok pegiat kesenian orkes gambus yang tersebar di sebagain besar wilayah Kabupaten Lampung Barat khususnya pada wilayah Kecamatan Sekincau, Kecamatan Batu Ketulis, Kecamatan Belalau, Kecamatan Batu Brak, dan Kecamatan Balik Bukit yang tentunya diujudkan dengan memberdayakan dan mengaktifkan kembali kelompok-kelompok pegiat kesenian orkes gambus yang tergabung dalam group-group orkes gambus sesuai dengan data yang telah kami rangkum dan sajikan pada Tabel 1 pada pembahasan sebelumnya yaitu data terkait dengan Gruop orkes gambus yang mengikuti pergelaran atau perlombaan "Pagelaran Virtual Orkes Gambus Tradisional Bumi Sekala Bekhak". Dengan aktif dan eksisnya group-group orkes gambus tersebut merupakan instrumen penting dalam upaya pelestarian kesenian orkes gambus di Kabupaten Lampung Barat.

Sebagai ulasan lebih terperinci mengenai upaya pelesatarian dan perlindungan terhadap kesenian orkes gambus yang dilakukan oleh kelompok masyarakat, penulis akan membagi upaya tersebut menjadi dua kategori kegiatan yaitu upaya pendokumentasian dan upaya pengenalan terhadap generasi muda. Pertama, upaya pendokumentasian dalam rangka melakukan perlindungan dan pelestarian kesenian orkes gambus lampung oleh masyarakat dilakukan dengan memanfaatkan perkembangan teknologi informasi dalam hal ini didokumentasikan berupa video-video pertunjukan dan pergelaran orkes gambus dalam berbagai acara dari setiap group-group orkes gambus yang ada. Hasil dari pendokumentasian tersebut tidak hanya disimpan sebagai dokumentasi yang aksesnya terbatas dalam kelompok masyarakat, akan tetapi dengan kemajuan teknologi informasi yang ditandai dengan banyaknya flatform-flatform digital turut dimanfaatkan oleh masyarakat sebagai media publikasi terhadap hasil pendokumentasian atas karya-karya pertunjukan kesenian orkes gambus tersebut yang salah satunya diantaranya dengan memanfaatkan platform digital youtobe.com.

Berdasarkan hasil penelitian ini, beberapa akun youtobe.com yang dikelola oleh para pegiat media sosial yang berasal dari kalangan masyarakat di Kabupaten Lampung Barat aktif mempublikasi konten-konten khusus tentang pertunjukan kesenian orkes gambus Lampung. Salah satu akun youtobe tersebut adalah akun dengan nama akun "RIDHO CHANNEL" (https://www.youtube.com/c/RIDHOCHANNEL Orkesgambuslampung/about) yang saat peneliti mengakses akun tersebut pada tanggal 25 Maret 2021 jumlah subscribernya mencapai angka 9,17 ribu subscriber dengan vidio yang diupload mencapai 1.190 video yang sebagian besar adalah pertunjukkan kesenian 
orkes gambus lampung di Kabupaten Lampung Barat. Sesuatu yang patut diapresiasi mengingat akun tersebut yang dalam deskripsi akunnya baru mulai aktif pada 15 april 2019 dengan konten-konten yang dimuat khusus diperuntukkan sebagai wadah publikasi terhadap hasil-hasil karya pertunjukan orkes gambus lampung yang dilakukan oleh sebagian besar group orkes gambus dan para pegiat kesenian orkes gambus yang ada di Kabupten Lampung Barat lengkap dengan tema pertunjukan, nama group penampil, lokasi acara, nama penyanyi, pencipta lagu yang dinyanyikan dan bahkan memberikan deskripsi tentang makna dan peristiwa yang terkandung dalam lagu yang dibawakan. Akun youtube tersebut telah diterima dan mendapatkan banyak apresiasi dari masyarakat yang ditunjukkan dengan banyaknya masyarakat yang mengakses akun tersebut. Selain akun "RIDHO CHANNEL" beberapa akun youtobe.com yang berasal dari masyarakat di Kabupaten Lampung Barat yang melakukan hal yang sama dengan tujuan yang sama yaitu ikut andil untuk terus melestarikan kesenian orkes gambus lampung. Diantaranya akun youtobe.com dengan nama channel "Endang Guntoro Canggu" dengan jumlah subscriber 2,13 ribu subscriber, "HRK Canggu Channel" dengan jumlah subscriber mencapai 1,49 ribu subscriber, "Irfan Rinando" dengan jumlah subscriber mencapai 5,75 ribu subscriber, "ANDAN SAKA CHANNEL” yang merupakan channel group orkes gambus asal Pekon Sukaraja, "Ratai Channel”, dan masih banyak lagi akunakun dari berbagai group orkes gambus dan pegiat media sosial yang ada di Kabupaten Lampung Barat.

Dengan hadirnya channel-channel youtobe.com yang berisikan konten-konten khsus dari pegiat media sosial dan pegiat kesenian tradisional orkes gambus lampung sesuai dengan penjabaran diatas menunjukkan bahwa masyarakat Lampung Barat telah ikut aktif melakukan pelestarian dan perlindungan terhadap kesenian orkes gambus. Dengan demikian tujuan akhir dari upaya pelestarian dan perlindungan terhadap kesenian tradisional khususnya orkes gambus yang ada di Kabupaten Lampung Barat telah tercapai.

Kedua yang dapat dilakukan oleh kelompok masyarakat khususnya pegiat kesenian orkes gambus dalam rangka melestarikan kesenian tersebut yaitu pengenalan terhadap generasi muda. Berdasarkan hasil penelitian ini, upaya pelestarian tersebut telah diujudkan dengan berbagai metode dan kegiatan seperti yang dilakukan oleh Group Orkes Gambus Kilu Bimbing yang berada di Pekon Serungkuk, Kecamatan Belalau yang berupaya melestarikan kesenian Orkes Gambus Lampung dengan cara mengadakan 
pelatihan khusus terkait dengan orkes gambus Lampung terhadap generasi muda yaitu muda-mudi Pekon Serungkuk dengan cara menghadirkan pelatih yang berasal dari para sesepuh pegiat kesenian orkes gambus yang ada di Pekon Serungkuk. Berdasarkan Penuturan dari saudara ZA, AZ dan AB yang merupakan pelatih pada kegiatan pelatihan tersebut dalam wawancara via telepon pada bulan maret tahun 2021, saudara ZA menuturkan bahwa kegiatan pelatihan yang diinisiasi oleh masyarakat tersebut, dalam pelaksanaanya mendapatkan dukungan dari pemerintah Pekon Serungkuk dalam hal ini dukungan langsung dari Peratin dan Perangkat Pekon Serungkuk. Sedangkan menurut AZ yang dalam hal ini merupakan pelatih Piyul (Biyola) mengatakan bahwa hampir semua muda-mudi yang ada di Pekon Serungkuk yang sebagian besar merupakan generasi millenial turut andil didalam kegiatan ini yang terbagi dalam beberapa bagian sesuai dengan instrumen atau alat musik yang ada dalam orkes gambus Lampung. Dengan demikian pelatihan tersebut dapat melahirkan generasi penerus dalam pertunjukan orkes gambus lampung, mulai dari vocalis, pemain biyola, pemain gambus, pemain bass, gendang dan alat musik pendukung lainnya dalam pertunjukan kesenian orkes gambus.

Upaya-upaya pengenalan kepada generasi muda seperti ini tentunya telah terlebih dahulu diperaktikkan oleh para pegiat kesenian orkes gambus yang tergabung dalam group-group orkes gambus yang tersebar disebagian besar wilayah Kabupaten Lampung Barat khususnya yang berada di Kecamatan Kebun Tebu, Kecamatan Sekincau, Kecamatan Batu Ketulis, Kecamatan Belalau, Kecamatan Batu Brak dan Kecamatan Balik Bukit. Dari hasil penelitian ini menunjukkan bahwa beberapa Grup orkes gambus bahkan telah melahirkan generasi-generasi muda yang telah mahir melakukan pertunjukan orkes gambus bahkan menorehkan prestasi. Salah satu dari group orkes tersebut telah melahirkan generasi penerus yaitu OG Andan Muakhi Umbul Liyoh yang telah dinobatkan sebagai pemenang untuk kategori penampil millenial dalam Pagelaran Virtual Orkes Gambus Tradisional Bumi Sekala Bekhak. Begitu juga yang dilaukan oleh grup orkes gambus HRK Canggu yang telah dikenal dengan dua penyanyi ciliknya yang baru berumur 9 Tahun yaitu Aura dan Aurel dengan iringan musik orkes gambus dari para pemuda Pekon Canggu (https://www.youtube.com/watch?v=craMs9kj1jU) akses 5 April 2021.

Selain beberapa upaya diatas, keberhasilan KTI Pekon Sukaraja, Kecamatan Batu Brak sebagai penyelenggara pertival orkes gambus tingkat Kabupaten Lampung Barat 
yang diselenggarakan pada bulan november tahun 2019 menunjukkan bahwa upayaupaya pengenalan terhadap orkes gambus tidak hanya dilakukan oleh para sesepuh pegiat kesenian orkes gambus di Lampung Barat tetapi dapat dilakukan dengan adanya peran aktif dari generasi muda itu sendiri. Kegiatan-kegiatan yang bertajuk latihan bersama antar sesama grup orkes gambus yang dalam bahasa daerah lampung barat lebih dikenal dengan istilah "Anjau Silau" juga merupakan bagian dari upaya pengenalan kesenian ini. Dengan rutinnya pergelaran orkes gambus yang dilakukan oleh groupgroup orkes seperti yang dilakukan oleh Grup Orkes Way Ghemelay Pekon Turgak, Andan Saka Sukaraja, Andan Mupakat Gunung Sugih, Sanggar Banjar Masin Padang Cahya, Diwangga Way Mengaku, Andan Muakhi Umbul Liyoh, Angon Saka Pekon Wates, Ratai Grup Pekon Sukarami, Saliwa Grup, Sang Muakhi bahway, Andan Jejama Kota Agung Liwa, Sanggar Sebarus Sai, Radeka Kesugihan Baru, Mutiara Group Kurungan Aji, Sinar Pesagi bahway, Janji Muakhi, Andan Jejama Titi Jelatong, Gema Musik Tembelang, Sumbay Sukajaya, Semulli Pekon Balak, Andan Jejama Gunung Sugih, Salui Pitu, Sanggar Buay Belajan Diway, Teba Liokh, HRK Canggu, Sanggar Jejama Pekon Awi, OG Way Bupitu Bakhu, Gemuttukh Agung, OG Seandanan Way Ngison, OG Bakhnasi, Punyimbang Bawang Limbang, Angkon Jejama Turgak, Buay Benyata Pekon Luas, Kilu Andan Penengahan Turgak, Kilu Bimbing Pekon Serungkuk, Sanggar Luppak Way Bumi Agung, Andan Muakhu Group Kenali, Pelimpuhan Kebun Tebu, Himpun Muakhi Pura Mekar, dan OG Seakkonan Sekincau secara tidak langsung telah melakukan pengenalan terhadap generasi muda, generasi penerus kesenian orkes gambus di Lampung barat pada masa yang akan datang.

Pada bagian akhir ulasan mengenai upaya perlindungan kesenian tradisional ini, upaya perlindungan secara hukum berkaitan dengan orkes gambus di Kabupaten Lampung Barat belum merupakan hal yang mendesak untuk dilakukan mengingat orkes gambus di Kabupaten Lampung Barat dipertunjukkan dengan menggunakan bahasa daerah yang ada di Kabupaten Lampung Barat yaitu Bahasa Lampung yang sangat berbeda dengan bahasa-bahasa dari daerah lainnya, sehingga upaya perlindungan secara hukum yang notabene ditujukan untuk melindungi agar kesenian ini tidak di klaim sebagai karya seni oleh pihak lain dirasa bukan merupakan sesuatu yang mendesak untuk dilakukan. 


\section{UPAYA PENGEMBANGAN ORKES GAMBUS LAMPUNG}

Selain upaya perlindungan dan pelestarian agar kesenian dan budaya lokal tidak terjadi kepunahan perlu kiranya ada upaya pengembangan terhadap kesenian dan budaya lokal tersebut. Terkait dengan penelitian ini, upaya pengembangan terhadap Kesenian Orkes Gambus Lampung yang ada di Lampung Barat dapat dilakukan oleh seluruh masyarakat khususnya para pegiat kesenian Orkes Gambus Lampung. Pengembangan yang dimaksud dalam hal ini ialah upaya pengolahan yang menghasilkan peningkatan mutu sehingga dapat membawa musik tradisional orkes gambus ini ke arah yang lebih modern serta memperluas jangkauan akses terhadap kesenian orkes gambus ini, agar dikenal tidak hanya oleh kalangan masyarakat Lampung tetapi diharapkan dapat dikenal oleh masyarakat secara luas.

Upaya peningkatan mutu terhadap orkes gambus ini diujudkan dengan munculnya aransemen-aransemen baru yang merupakan hasil karya seni para pegiat kesenin orkes gambus Lampung. Perlu diketahui bahwa sebagaimana dijabarkan pada pendahuluan dalam penelitian ini, dari segi alat musik yang digunakan pada mulanya orkes gambus Lampung hanya menggunakan alat musik berupa Gambus, ketipung ( gendang ), piyul ( biola ), meruas ( tamborine ) dan Bas akan tetapi seiring berjalannya waktu pergelaran orkes gambus juga telah menggunakan alat musik yang lebih modern yaitu alat musik keyboard. Upaya lain yang dilakukan para penggiat orkes gambus lampung di lampung barat yaitu membuat aransemen dengan memadukan alat musik khas orkes gambus lampung dengan alat musik tradisional lainnya sehingga aransemen yang dihasilkan lebih indah dan memperkaya instrumen musik dalam orkes gambus. Hasil nyata dari upaya penggabungan instrumen orkes gambus dengan alat musik tradisional lainnya diujudkan dengan adanya kombinasi aransemen orkes gambus dengan alat musik tradisional yang juga berasal dari Lampung Barat yaitu Gamollan Pekhing (Gamelan Bambu). Berdasarkan informasi yang peneliti peroleh dari akun youtube.com "Endang Guntoro Canggu" yang merupakan salah satu pegiat orkes gambus Lampung (https://www.youtube.com/watch?v=Wn2czlECpjs) di akses pada 2 april 2021. Dalam deskripsi pada akun tersebut disebutkan bahwa aransemen yang dihasilkan berkat kerjasama antara SRC Music Bandar Lampung bekerjasama dengan maestro gamollan pekhing yaitu Safril Yamin (Mamak Lil) dengan membawakan lagu Pagun Ingok ciptaan Alm. Basnal Maas dengan vocal Seem. R. Canggu, S.E., MM (Raja Duta Perbangsa). Lain halnya yang dilakukan oleh Irfan Rinando yang memilih mengaransemen lagu-lagu khas 
orkes Gambus Lampung hanya dengan menggunakan alat musik gitar. Dalam kesenin Orkes Gambus Lampung aransemen musik yang digunakan terdiri atas tiga bagian yaitu aransemen yang menggunakan lebih dari satu alat musik (Orkes Gambus), aransemen yang hanya menggunakan alat musik gambus (Gambus Tunggal) dan aransemen musik yang hanya menggunakan alat musik gitar (Gitar Tunggal). Dari ketiga arasnsemen musik tersebut Gambus Tunggal dan Gitar Tunggal identik dengan aransemen musik yang bernuansa kesedihan, pesan-pesan yang disampaikan juga berupa petuah-petuah Lampung yang sebagian besar merupakan pengalaman hidup yang begitu pedih yang disampaikan melalui musik. Berbeda dengan arasnsemen yang dilakukan oleh saudara Irfan Rinando yang dipublikasi dalam akun youtobe.com miliknya (https://www.youtube.com/channel/UCAhOz_UFmh7z17GpWB-v4dA) akses 5 April 2021. Aransemen musik yang dibawakan bernuansa lebih modern dengan sekmen penikmat musiknya adalah generasi muda (Generasi Millenial). Dengan adanya perpaduan dari berbagai alat dan inovasi terkait aransemen tersebut menunjukkan bahwa proses pengembangan pada orkes gambus Lampung terus dilakukan sehingga menambah khasanah bermusik dalam kesenin orkes gambus lampung.

\section{UPAYA PEMANFAATAN ORKES GAMBUS LAMPUNG}

Setalah upaya perlindungan dan pengembangan, upaya selanjutnya yang dapat dilakukan adalah upaya untuk memanfaatkan hasil dari pengembangan terhadap kesenian dan kebudayaan lokal tersebut. Pemanfaatan yang dimaksud dapat dilakukan dengan cara melakukan upaya-upaya untuk menggunakan hasil-hasil kesenian dan kebudayaan untuk berbagai keperluan. Berkaitan dengan perihal tersebut, dalam hal upaya untuk memanfaatkan kesenian orkes gambus Lampung di Kabupaten Lampung Barat untuk berbagai keperluan telah dilakukan dengan cara melibatkan kesenian orkes gambus Lampung dalam berbagai kegiatan yang ada didalam masyarakat maupun kegiatan-kegiatan yang dilaksanakan oleh pemerintah daerah. Bukti nyata pemanfaatan Orkes Gambus Lampung di Kabupaten Lampung Barat yaitu keterlibatan para pegiat dan group kesenian orkes gambus lampung dalam berbagai acara penting yang diselenggarakan oleh pemerintah daerah diantaranya keterlibatan sanggar (Group) orkes gambus dalam acara penutupan Festival Sekala Bekhak VI tahun 2019. Sebagai mana dikutip dari akun youtube.com "Endang Guntoro Canggu” yang merupakan Kepala Bidang Pemasaran Pariwisata pada Dinas Kepemudanaan, Olahraga dan Pariwisata 
Kabupaten Lampung Barat (https://www.youtube.com/watch?v=YOZPVDBGkGA), di dalam deskripsi pada channel youtube.com tersebut disebutkan bahwa selama ini pemerintah daerah telah melibatkan group orkes gambus untuk tampil dalam berbagai kegiatan yang diselenggarakan oleh pemerintah daerah. Dalam deskripsi tersebut disebutkan juga bahwa group orkes yang sering diundang untuk tampil diantaranya, Sanggar Sebarus Sai, HRK Canggu dan Sanggar Buay Bejalan Diway. Sedangankan pada acara penutupan Festival Sekala Bekhak VI tahun 2019 tersebut, group orkes gambus Lampung yang diundang pemerintah daerah untuk tampil adalah Sanggar Way Ghemelay Pekon Turgak.

Selain keterlibatan Orkes Gambus Lampung dalam kegiatan yang diselenggarakan oleh pemerintah daerah, pemanfaatan keberadaan kesenian ini juga dimanfaatkan oleh kalangan masyarakat Lampung Barat sebagai sarana hiburan dalam acara-acar penting adat dan acara-acara keluarga seperti resepsi pernikahan, khitanan, Bediom (menempati rumah baru) dan acara-acara lainnya. Keterlibatan Group Orkes Gambus Lampung dalam acara Bediom Lamban Dinas (Rumah Dinas) Wakil Bupati Lampung Barat pada tahun 2019 sebagai salah satu contoh bahwa orkes gambus dapat dimanfaatkan sebagai alternatif hiburan dalam acara-acara penting ditengah masyarakat (Sumber akun youtobe.com RIDHO CHANNEL: https://www.youtube.com/watch?v=snVLSPTMhyo). Dengan cara-cara pemanfaatan tersebut akan menjadikan Orkes Gambus Lampung terus lestari serta lebih dikenal untuk menunjang eksistensi Kabupaten lampung Barat dalam bidang Kesenian dan kebudayaan.

\section{KESIMPULAN}

Berdasarkan hasil temuan dan data yang telah disajikan serta dianalisis pada penelitian ini dapat disimpulkan bahwa Upaya Pelestarian Kesenian Orkes Gambus di Kabupaten Lampung Barat tidak hanya dilakukan oleh pemerintah daerah tetapi pelestarian juga dilakukan oleh kelompok masyarakat. Adapun upaya pelestarian yang dilakukan dibagi menjadi tiga bagian yaitu Pertama, upaya perlindungan yang dilakukan dengan melakukan pendokumentasian dengan memanfaatkan kemajuan teknologi informasi yaitu pemanfaatan flatform digital youtube.com serta upaya pengenalan kepada generasi muda yang dilakukan dengan cara memberikan pelatihan-pelatihan cara berkesenian orkes gambus oleh para pegiat kesenian orkes gambus yang tersebar pada group-group oreks gambus yang ada di Kabupaten Lampung barat. Kedua, Upaya 
pengembangan orkes gambus Lampung dilakukan dengan membuat inovasi aransemen yang dihasilkan dari perpaduan antar kesenian orkes gambus lampung dengan beberapa instrumen musik lainnya seperti alat musik keyboar dan Gamollan Pekhing. Ketiga, Upaya memanfaatkan kesenian orkes gambus dilakukan dengan cara memberikan ruang tampil bagi para pegiat dan group-group kesenian orkes gambus pada acar-acara yang diselenggarakan oleh Pemerintah Daerah maupun acara yang dilaksanakan oleh masyarakat.

\section{REFERENSI}

A.W Widjaja. (1986). Individu, Keluarga Dan Masyarakat. Jakarta: Akademika.

Depdiknas . (2001). Kamus Besar Bahasa Indonesia. Jakarta: Balai Pustaka.

Maheswara, Fathan. (2020). Grup Orkes Gambus Dian Utama Di Pekon Padang Dalom, Kecamatan Balik Bukit, Kabupaten Lampung Barat. Skripsi. Yogyakarta: Jurusan Etnomusikologi Institut Seni indonesia.

Moh. Nazir. (1998). Metode Penelitian. Jakarta: Ghalia Indonesia.

Ranjabar, Jacobus.( 2006). Sistem Sosial Budaya Indonesia. Bogor :Ghalia Indonesia.

Suharto, Edi. (2006). Membangun Masyarakat Memberdayakan Rakyat. Bandung: Rafilka Aditama.

lampungbaratkab.go.id. (2016, 06 Desember). Budaya. Diakses pada 10 April 2021, dari: https://lampungbaratkab.go.id/detailpost/budaya.

lampungbaratkab.go.id. (2019, 22 Oktober). Festival Orkes Gambus Akan Digelar November. Diakses pada 10 Maret 2021, dari: https://lampungbaratkab.go.id/detailpost/festival-orkes-gambus-akan-digelarnovember.

medialampung.co.id. (2019, 11 November). KTI Lambar Sukses Gelar Festival Budaya Orkes Gambus. Diakses pada 10 Maret 2021, dari: https://medialampung.co.id/ktilambar-sukses-gelar-festival-budaya-orkes-gambus/.

youtobe.com. (2020, 17 Oktober). Daftar Penerima Apresiasi Pagelaran Virtual Orkes Gambus Tradisional Bumi Sekala Bekhak 2020. Diakses pada 15 Maret 2021, dari: https://www.youtube.com/watch?v=sW7n1JLjEDY\&t=409s.

youtobe.com. (2019, 15 April). RIDHO CHANNEL. Diakses pada 25 Maret 2021, dari: https://www.youtube.com/c/RIDHOCHANNELOrkesgambuslampung/about. 
youtobe.com. (2021, 17 Januari). KHUBAH JANJI // Cipt : Saleh Gunawan // Cover : Aura \& Aurel //Arr : HRK Canggu Junior. Diakses pada 25

Maret 2021, dari: https://www.youtube.com/watch?v=craMs9kj1jU.

youtobe.com. (2020, 18 September). Lagu Lampung Tumbai PAGUN INGOK Cipt. Basnal Maas Vocal. Seem R Canggu (SRC) Raja Duta Perbangsa. Diakses pada 2 April 2021, dari: https://www.youtube.com/watch?v=Wn2czlECpjs.

youtobe.com. (2017, 26 Januari). Irfan Rinando. Diakses pada 5 April 2021, dari: https://www.youtube.com/channel/UCAhOz_UFmh7z17GpWB-v4dA.

youtobe.com. (2019, 13 Juli). Orkes Gambus Sanggar Way Khemelai / Festival Sekala Bekhak VI. Diakses pada 25 Maret 2021, dari: https://www.youtube.com/watch?v=YOZPVDBGkGA.

youtobe.com. (2019, 15 Oktober). Orkes Gambus Lampung Dalam Acara Bediom Lamban Dinas Wakil Bupati Lampung Barat. Diakses pada 18 April 2021, dari: https://www.youtube.com/watch?v=snVLSPTMhyo. 